\title{
Does "Y" Generation Managers Attributes is Associated with Technology Adoption Behavior?
}

\author{
Normala, S. Govindarajo, *Dileep Kumar M. \\ Othman Yeop Abdullah Graduate School of Business, Universiti Utara Malaysia \\ *dileep@uum.edu.my
}

\begin{abstract}
It is a dilemma to professionals that whether they should adopt technology to improve their functional contributions and thereby enhance business performance. Changes in the generations have different approaches to adopt technology application in their work life. As we see the differences in Generation X and Generation Y, in their features and characteristics, it is hypothesized that such differences also expect in professional approach in the adoption of technology for effective functional dissemination. This particular study follows a qualitative research methodology that to explore the relationship between Generation Y professionals in their attitude towards adoption of technology in business operations.
\end{abstract}

Keywords: Managers, technology adoption, behavior, performance

\section{Introduction}

Many definitions of "generation" have been propounded by many authors. Generation means groups, which are identifiable in terms of year of birth, age, location, and significant events, which molded their persona. The life experiences shape their personality and influence their value system, that help one identify as to what is right and what is wrong. In order to increase organizational effectiveness, particularly in relationship with the workers, the managers need to identify the generational differences (Smola \& Sutton, 2002). According to Kupperschmidt (2000) a generation as an identifiable group, or cohort, which shares birth years, age, location, and significant life events at critical developmental stages. Currently there are three main generations in the workplace: Baby Boomers (born 1946 to 1964), Generation X (born 1965 to 1977) and Generation Y (born 1978 to 1994). We draw our categorization from Kupperschmidt (2000) and Smola \& Sutton (2002). The values of Generation Xers differ from that of the Generation Nexters who are optimistic and have a sense of civic duty, are confident and achievement oriented (Arsenault, 2004). These values are different from that of the baby boomers, who is more optimistic having a sense of personal gratification and growth. The values of the workforce have undergone considerable changes influenced by generational experiences rather than by maturity and age (Smola \& Sutton 2002). However, such discussion was going on our study focus more on generation and their intention towards technology adoption. In order to explore the relationship between technology adoption and generation characteristics, it is necessary to distinguish between Generation $\mathrm{X}$ and Generation Y. The below mentioned recent literature, in general, demarcate the characteristic feature of Generation $\mathrm{Y}$ and Generation X, give more insight into the exploring research area.

Generation X and Generation Y: It has been noted by many research scholars (Egri \& Ralston, 2004; Smola \& Sutton, 2002; Crumpacker \& Crumpacker, 2007) noted that in the middle cohort of current working generations, referred to as Generation X, was born between the years 1965 and 1979 and it has the least amount of people of the three generations under review. This Generation X grew up with both parents in the workforce, or in a divorced household, and as a result, many were latchkey kids, becoming independent at a young age (Crumpacker \& Crumpacker, 2007; Weingarten, 2009). Generation X carried the trend of distancing themselves from companies just as the Baby Boomers did (Dries et al., 2008), making them distrustful of organizations (Westerman \& Yamamura, 2007). It is testified that Generation $\mathrm{X}$ comes in the workforce challenging with the Baby Boomers for jobs during the 1980s' recession, which ended many of these individuals cynical towards the older generation (Crumpacker \& Crumpacker, 2007). While, dominant literature agrees on Generation Y beginning in 1980 (Smola\& Sutton, 2002; Weingarten, 2009; Crumpacker \& Crumpacker, 2007; Essinger, 2006) and ending in 2000 (Clark, 2007). Generation Y also called as are "Millennials" (Howe \& Strauss, 2000), "Next Generation" (Shaw \& Fairhurst, 2008), and "Generation Next" (Loughlin \& Barling, 2001; Zemke, Raines, \& Filipczak, 2000; Martin, 2005). Martin (2005) describes Millennials as independent, confident, and self-reliant. This may be due to the extensive protection and praise given to them throughout their formative years 
(Crumpacker \& Crumpacker, 2007). In business, Generation Y exhibits the propensity for working in teams while being collaborative, results-oriented individuals, and having an ardor for pressure (Shih \& Allen, 2007).

\begin{tabular}{|c|c|}
\hline Generation & Salient features \\
\hline GIs & $\begin{array}{l}\text { Brave and fearless, dedicated to progress and innovation, optimists, rationalists, } \\
\text { builders, doers, less spiritual, more concerned with outer life over inner, collegial, } \\
\text { standardized, pre-packaged, bland, trusting in government and authority, civic-minded }\end{array}$ \\
\hline Silent's & $\begin{array}{l}\text { Preferring job security over entrepreneurship, cautious, unimaginative, unadventurous, } \\
\text { unoriginal, facilitators and helpmates, arbiters but not leaders, causeless, without } \\
\text { outward turmoil, inward-focused, sandwiched in between the GI and Baby Boom } \\
\text { generations }\end{array}$ \\
\hline Boomers & $\begin{array}{l}\text { Much heralded but failing to meet expectations, smug, self-absorbed, intellectually } \\
\text { arrogant, socially mature, culturally wise, critical thinkers, spiritual, religious, having an } \\
\text { inner fervor, radical, controversial, non-conformist, self-confident, self-indulgent }\end{array}$ \\
\hline Gen X & $\begin{array}{l}\text { Cynical, distrusting, bearing the weight of the world, fearful, lost, wasted, incorrigible, } \\
\text { in-your-face, frenetic, shocking, uneducated, shallow, uncivil, mature for their age, } \\
\text { pragmatic, apathetic and disengaged politically, independent, self-reliant, fatalistic, } \\
\text { mocking, under-achieving }\end{array}$ \\
\hline Millennial/ & $\begin{array}{l}\text { Optimists, cooperative, team players, trusting, accepting of authority, rule-followers, } \\
\text { smart, civic-minded, special, sheltered, confident, achieving, pressured, conventional }\end{array}$ \\
\hline
\end{tabular}

Notes: descriptions from Strauss \& Howe (1991)

This study seeks to contribute to the empirical works on generational differences at work in technology adoption examining generational characteristic features.

Gen Y Recruiting and Management Strategies

\begin{tabular}{llll}
\hline Gen Y Characteristic & Recruiting strategy & Management strategy \\
\hline $\begin{array}{l}\text { Strong sense of } \\
\text { morality }\end{array}$ & $\begin{array}{l}\text { Demo the significance of the position } \\
\text { and the role the individual will fulfill } \\
\text { within the organization }\end{array}$ & $\begin{array}{l}\text { Explain the important of the tasks } \\
\text { and functions performed by the } \\
\text { employee }\end{array}$
\end{tabular}

Goal and achievement Identify opportunities to advance, and oriented communicate them to potential recruits

Digital natives Use the internet as a recruiting tool for companies

Value intelligence, Focus on challenges, growth innovation and opportunities, and contributions to frequently feedback the organization; describe the progression up the organizational ladder

Value work and family Highlight benefits packages and work balance schedule flexibility

Multitasks

Turn off their cell phone to avoid interruptions during an interview or office visit

Clearly delineate expectations

Encourage computer technologies to make the organization more efficient, encourage technological innovations

Work with employees to develop the ability to accept and synthesize constructive comments

Provide good benefits packages; increase work schedule flexibility; minimize excessive overtime and travel

Explicitly describe the organization rules concerning the use of companies, cell phones and tablet during office hours.

Group work and Evaluate skills during the recruitment collaboration process to hire team building nature 


\section{Interviews with HR Managers}

In order to understand managers perception on $\mathrm{X}$ and $\mathrm{Y}$ Generation this particular study organized three interviews with senior HR managers from three industries belong to different sectors. The comprehended form of such interviews can be detailed as follows.

"The Generation Y managers are more loyal to the organization and are well committed to organizational mission. The Y Generation HR manager is more close to technology and they adopt technology based recruitment process, which is time saving and cost cutting, compared to traditional mode of recruitment. High extroversion, friendliness, team orientation, proactiveness and self-confidence that support them to accept the risk and adopt new technology which bring more business development opportunities to the organization." (A.P. Hari, HR Manager, Maxis, Malaysia).

"In the adoption of technology in functional application, I do believe that Generation $Y$ mangers are more committed to, learn fast and apply the new knowledge in the field compared to $X$ Generation managers. Companies are working with people and technology. The performances of the employees are crux to any business organization's development. Adoption of technology in performance management system is significant in ensuring appropriate target accomplishments. We look upon Y Generation managers more to our company than an $X$ Generation, whom are result oriented and more loyal to organizations"

(Guvindran, HR Head, Continental Tyres, Malaysia).

"Communication is a very much important function in management professions. Interact with customers, distributors, suppliers, employees and all stakeholders of business is the major function of any managers. It is widely observed that the $Y$ Generation managers are more prone towards effective communication with their stakeholders and stabilize the business opportunities compared to $X$ Generation managers. The $Y$ Generation managers are more business and organization oriented compared to X Generation managers. " (Mr. Ahmed Fiaza Abdul Shukor, Metro Parking, Malaysia).

\section{Methodology}

The methodology of research followed in this study was Delphi technique, which provided exploratory insight into leadership characteristics and technology adoption. The Delphi technique, mainly developed by Dalkey and Helmer (1963) at the Rand Corporation in the 1950s, is a widely used and accepted method for achieving convergence of opinion concerning real-world knowledge solicited from experts within certain topic areas. Predicated on the rationale that, "two heads are better than one, or...n heads are better than one (Dalkey, 1972), the Delphi technique is designed as a group communication process that aims at conducting detailed examinations and discussions of a specific issue for the purpose of goal setting, policy investigation, or predicting the occurrence of future events (Ulschak, 1983; Turoff \& Hiltz, 1996; Ludwig, 1997). The Delphi method is especially useful for long-range forecasting (20-30 years), as expert opinions are the only source of information available.

Respondent Identification: The group of Generation Y from various industry age between 30 to 40 and all from supervisor level and above. This research engaged semi-structured interviews. Based on the suitable time for the resource person interviews were arranged, during 2012 March 1 $1^{\text {st }}$ to 2013 March 31 st. Telephonic interview is conducted to gather information from the respondents. All the clarifications related to the objective of the study were made by the researcher. However, out of 25 respondents were being interacted and communicated; only 20 participants were interviewed by telephone and through email. The conversations taped recording, and manually analyzed. The procedural steps in adopting the Delphi technique were as follows.

Expert Panel Identification: 30 experts from the industry and academia were identified and approached by email or telephone and were invited to take part in the study. Finally, 20 experts were shown their willingness to participant in the discussion. The group of professional was made from specialists having high knowledge and expertise in the field of Generation $\mathrm{X}$ and $\mathrm{Y}$ and technology adoption. They are closely associated with industries, as Consultants, Top level managers, Researchers and Academicians. The specialized areas of these expert members include, 15 male members $(75 \%)$ and 5 female members (25\%). These dynamic groups of panel of experts are knowledgeable and familiar to give relevant opinions and an admissible understanding of Generation $\mathrm{X}$ and $\mathrm{Y}$ and technology adoption.

\section{Data Collection}

Round 1: In the first round, the Delphi process traditionally begins with an open-ended questionnaire. The open-ended questionnaire serves as the cornerstone of soliciting specific information about a content area from the Delphi subjects (Custer, Scarcella, \& Stewart, 1999). 


\section{The questions}

- How do you define $\mathrm{X}$ and $\mathrm{Y}$ Generation?

- What are the basic characteristic features in a manager, who favor adoption of technology in functional dissemination?

- How far the managers of $\mathrm{X}$ and $\mathrm{Y}$ Generation is linked to technology adoption?

Round 2: In the second round, each Delphi member receives a second questionnaire and is asked to review the items summarized by the investigators based on the information provided in the first round. Accordingly, Delphi panelists may be required to rate or rank-order items to establish preliminary priorities among items. Because of round two, areas of disagreement and agreement are identified (Ludwig, 1994). In this round, consensus begins forming and the actual outcomes can be presented among the participants' responses (Jacobs, 1996). Information regarding the influential factors of $Y$ Generation that linked to technology adoption was collected from the respondents. The process identifies 103 categories, which are having items with high and low proximity of managers' characteristic with Y Generation is identified on 22 factors. Rating process further identified in the categories and items identified.

Round 3: In the third round, each Delphi panelist receives a questionnaire that includes the categories and items ratings, summarized by the investigators in the previous round and are asked to revise his/her judgments or "to specify the reasons for remaining outside the consensus" (Pfeiffer, 1968). This round gives Delphi panelists an opportunity to make further clarifications of both the information and their judgments about the relative importance of the categories and items. Second level screening of the 103 categories, which were having a high and low influence on technology adoption of business identified with corresponding items. The process further identified 58 categories, which are having high and low proximity of managers characteristic with Y Generation is identified. Classification of the items in 58 categories of 12 factors was being made with appropriate loaded items. Thematic presentation and the categorization of the items were done.

Round 4: In the fourth and often final round, the list of remaining items, their ratings, minority opinions, and items achieving consensus are distributed to the panelists. This round provides a final opportunity for participants to revise their judgments. It should be remembered that the number of Delphi iterations depends largely on the degree of consensus sought by the investigators and can vary from three to five (Van de Ven, Gustafson, 1975; Ludwig, 1994). During third level, screening of the 38 categories among 7 factors, which were having, items with high and moderately high proximity of managers of $Y$ Generation is identified. Sought the expert opinion on the appropriateness of the core factors selected for the study.

\section{Results}

\begin{tabular}{|c|c|c|c|c|c|}
\hline $\begin{array}{l}\text { Managerial } \\
\text { characteristics } \\
\text { (Y Gen) S/N }\end{array}$ & Factors & Categories & $\begin{array}{l}\text { No. of } \\
\text { Items }\end{array}$ & $\begin{array}{c}\text { No of } \\
\text { Experts } \\
(\mathrm{N}=20)\end{array}$ & $\begin{array}{c}\text { \% of } \\
\text { Experts }\end{array}$ \\
\hline \multirow[t]{6}{*}{1} & Visionary & Inspirational & 4 & 14 & $74 \%$ \\
\hline & & Working with Imagination & 3 & 14 & $74 \%$ \\
\hline & & Insight & 4 & 16 & $71 \%$ \\
\hline & & Boldness & 4 & 14 & $70 \%$ \\
\hline & & Inner spiritual force & 3 & 14 & $70 \%$ \\
\hline & & Shared vision & 3 & 15 & $75 \%$ \\
\hline \multirow[t]{7}{*}{2} & Group Orientation & Generosity & 3 & 14 & $73 \%$ \\
\hline & & Sharing & 3 & 14 & $73 \%$ \\
\hline & & Group wisdom & 3 & 15 & $75 \%$ \\
\hline & & Responsibility to self & 4 & 15 & $75 \%$ \\
\hline & & Work for group & 4 & 14 & $74 \%$ \\
\hline & & Mutual concern & 4 & 14 & $74 \%$ \\
\hline & Emotional & Emotional Maturity & 4 & 16 & $78 \%$ \\
\hline \multirow[t]{4}{*}{3} & Intelligence & Constructive perception & 3 & 16 & $78 \%$ \\
\hline & & Transparent & 4 & 15 & $75 \%$ \\
\hline & & Adaptable & 4 & 15 & $76 \%$ \\
\hline & & Committed to people & 4 & 15 & $76 \%$ \\
\hline 4 & Transformational & Articulating a vision & 3 & 15 & $76 \%$ \\
\hline
\end{tabular}




\begin{tabular}{|c|c|c|c|c|c|}
\hline & & Leading by example & 3 & 16 & $79 \%$ \\
\hline & & optimistically & 3 & 16 & $79 \%$ \\
\hline & & risks with & 3 & 15 & $76 \%$ \\
\hline & & $\begin{array}{l}\text { followers } \quad \text { Stressing } \\
\text { values }\end{array}$ & 4 & 15 & $75 \%$ \\
\hline \multirow[t]{6}{*}{5} & Stakeholder & Concern to people & 3 & 15 & $77 \%$ \\
\hline & Orientation & Concern to investors & 3 & 16 & $78 \%$ \\
\hline & & Concern to employees & 3 & 15 & $77 \%$ \\
\hline & & Concern to customers & 3 & 16 & $78 \%$ \\
\hline & & Concern to supplies & 3 & 15 & $75 \%$ \\
\hline & & Concern to distributors & 3 & 15 & $75 \%$ \\
\hline \multirow[t]{6}{*}{6} & $\begin{array}{l}\text { Strategic } \\
\text { Orientation }\end{array}$ & $\begin{array}{l}\text { Fostering innovative } \\
\text { thinking }\end{array}$ & 3 & 16 & $78 \%$ \\
\hline & & Face challenges & 3 & 16 & $78 \%$ \\
\hline & & $\begin{array}{l}\text { Community and market } \\
\text { centric }\end{array}$ & 3 & 14 & $70 \%$ \\
\hline & & Adaptable & 4 & 16 & $80 \%$ \\
\hline & & Manage uncertainty & 3 & 16 & $79 \%$ \\
\hline & & $\begin{array}{l}\text { Reflexivity } \\
\text { analysis) }\end{array}$ & 3 & 14 & $70 \%$ \\
\hline \multirow[t]{4}{*}{7} & Relationship & Encouragement & 3 & 15 & $76 \%$ \\
\hline & Management & Change catalysis & 3 & 16 & $80 \%$ \\
\hline & & Conflict tolerance & 3 & 15 & $76 \%$ \\
\hline & & Develop other & 3 & 16 & $80 \%$ \\
\hline
\end{tabular}

The first factor considered for the study is the visionary nature of leaders in relation to Generation Y. The experts acknowledged 21 items. The major factor visionary nature consists of 6 subcategories. Though the experts did not point out much variation in these categories, the table shows Shared vision $(75 \%)$ and Inner Spiritual Force (70\%) as the major factor, which stimulates the business owner's decision to go with technology adoption. Further the study also pointed out the sub categories like Inspirational nature (74\%) and Working with imagination (74\%), insight (74\%) and boldness (70\%) as the features that lead them to give more thrust to go with technology adoption (21 items). The second factor considered for the study is the group orientation nature. Within the second factor, the experts identified 21 items that are closely related to leader's attitude to go with technology adoption. The major factor of group orientation nature consists of 6 sub-categories. The table showed Responsible to self (75\%) and Group wisdom (75\%), as the prominent factor which closely knit with leader's attitude for to go with technology adoption. Further, the study further pointed out the sub categories like mutual concern (74\%) and work for the group $(74 \%)$ as the second major subcategories that explain leaders of Generation Y. The observation also indicates generosity (73\%) and sharing nature of leaders (73\%) with Generation Y to go with technology adoption.

The third dimension that influence leader's attitude towards Generation Y to go with technology adoption is the Emotional Intelligence factors. The experts identified 19 items under 5 sub categories Emotional Intelligence. The result indicates that the Emotional Maturity (78\%) and Constructive Self Perception (78\%) as the prominent sub category, which influence Generation Y leaders. Further, the result also pointed out the leader's adaptable nature (76\%) and commitment to people $(76 \%)$ as the second prominent factors in relation Generation Y managers. Further, the observations clearly indicate a fine tune relation with the transparent nature $(75 \%)$ of the Generation Y leader to go with technology adoption. The fourth factor considered for the study is the transformational leadership style. The result indicates that the experts identified 16 items, which comes under 5 categories of transformational leadership style factors. The experts identified Leading by Examples (79\%) and Acting Optimistically (79\%) as the closest factor that related to leaders of Generation Y. Moreover, the result also shows the proper Articulation of Vision (76\%) and sharing risk with followers (76\%) which is closer to Generation $\mathrm{Y}$. The observation also pointed out value orientation element of the Generation Y leader by pointing the sub factor stressing values (75\%) to go with technology adoption. The fifth factor that influence leader's attitude towards to go with technology adoption is the stakeholder orientation. The experts identified 18 items under 6 sub factors in relation to Generation Y. The major sub factors identified by the experts are the Concern to customers (78\%) and Concern to Investors (78\%). Expert further observes concern for people $(77 \%)$ and concern to employees $(77 \%)$ as the second prominent sub factors. The expert also 
pointed out the other stake holder's importance in considering Generation Y, which includes Concern for Suppliers (75\%) and Concern for Distributers (75\%).

In the sixth factor, experts identified 19 items under 6 sub categories of the factor Strategic Orientation. Out of these 6 categories, the panel identified Reflexivity (70\%) and Community and Market Orientation $(70 \%)$ as the major factors related to leaders of Generation $Y$ to go with technology adoption. Further, the result also pointed out the sub categories like Managing uncertainty (79\%) and Adaptability (80\%) as closer factors in relation to Generation Y. In addition to the above factors, the experts also related the Fostering Innovation (78\%) and an attitude to Face challenges (78\%) in relation to the leader generation Y to go with technology adoption. The seventh factor or dimension is the Generation Y attitude towards technology adoption is the Relationship Management. The experts identified 12 items in the Relationship Management factor under 4 sub categories. The table shows Change catalyst (80\%) and develops others $(80 \%)$ as the major factors leaders of Generation $Y$ attitude towards technology adoption. Further, the study also pointed out the sub categories like Encouragement (76\%) and Conflict tolerance $(76 \%)$ as issues related to resource orientation, which intern acts as barrier to take a decision to go with technology adoption.

Discussion: This particular case study was conducted to identify the Y Generation characteristic features, which are closely knit with adoption of technology in business performance. The study observed 7 core factors, which are closely associated with Y Generation managers in their preference towards adoption of technology. These factors are visionary nature, group orientation, emotion intelligent, transformation leadership, stakeholder orientation, strategy orientation and relationship management. Out of this seven factors relationship management is closely related to Y Generation managers in their decision to adopt new technology for business performance. The relationship management is much more important in establishing effective diplomacy with all stakeholders. Technology support Y Generation managers have effective link with their stakeholders, saving time, energy and time that further support quick decision making in business. In addition to that, relationship management is much more important to have effective linkages with different level of managers. Technology adoption nature of Y Generation managers needs to be explained as a strategic move to have better decision making in business. The study further observed that the transformation leadership style of Y Generation mangers is closely linked to attitudes towards adoption the new technology. The objective of adoption of new technology with the integration of transformation leadership style is to bring broader changes in the organization in tune with external and internal business environmental changes. The Y Generation manager's transformational leadership style is explaining their far reaching objective of transforming their organizations with sustainable business practices.

\section{Factor Based Y Generation - Technology Adoption Model}

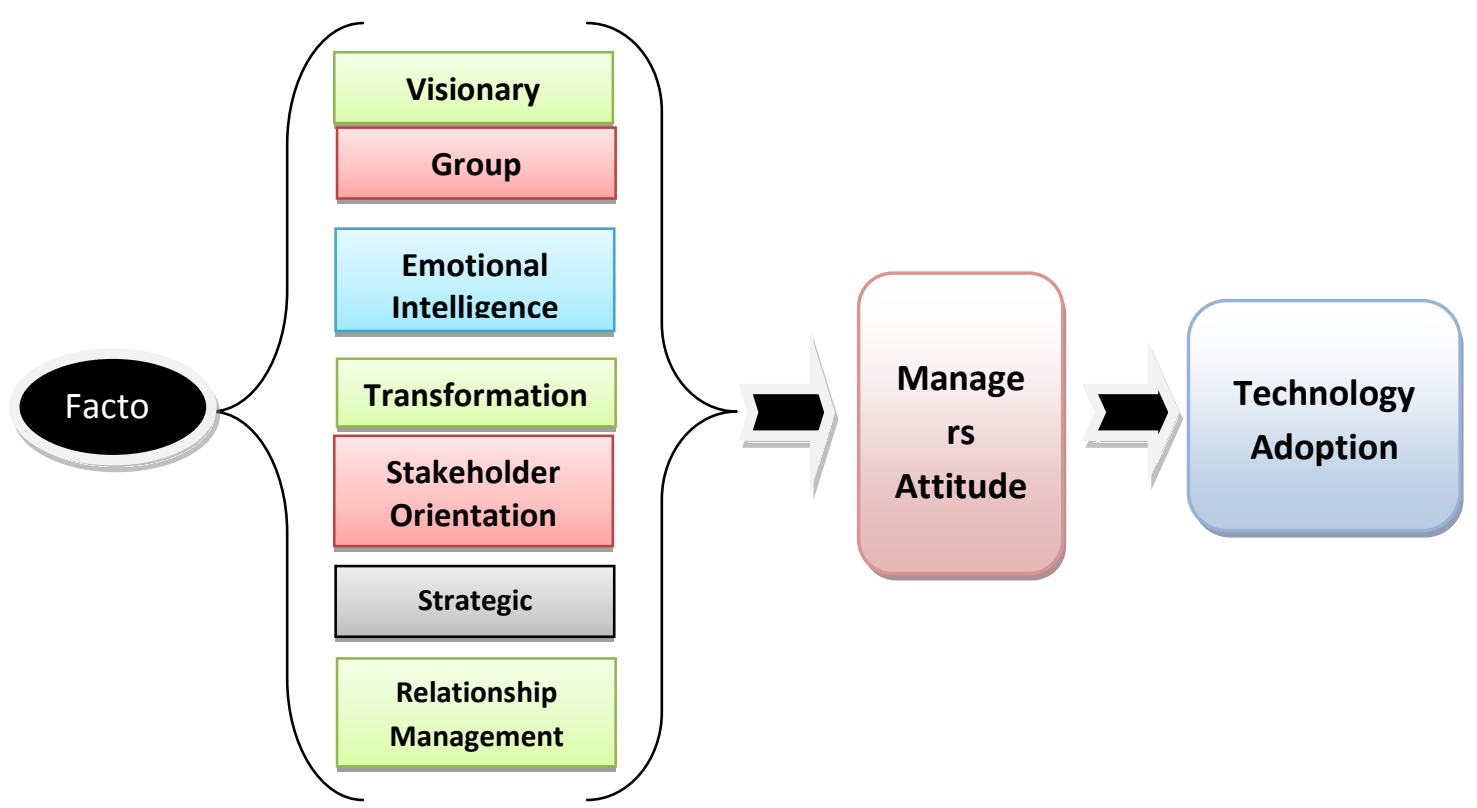

Another factors closely identified by the expert is the emotional intelligent nature of $\mathrm{Y}$ Generation managers in relation to adoption of new technology. It is important that the managerial decision should 
be communicated through and effective medium that devoid of confusion and ambiguity. The $Y$ Generation's manager's attitude towards technology adoption needs to be explained in such a way that it cling to their strategic orientation towards effective business performance. Business strategy is concerned with the activities and choices of the firms to position their self in market to achieve a high level of business performance. The nature of the strategy orientation of Y Generation managers with the adoption of technology application supports them to achieve their target by saving cost, energy and time. Thus, the adoption of the attitude to adopt technology is to be explained as Y Generation manager's mission towards business output. The experts also identified a better link between group orientation natures of Y Generation manager's with technology adoption. The Y Generation managers are having the business knowledge. To apply this knowledge in business technology adoption is needed. Technology provides better networking with groups and thereby ensuring better interaction between different levels of management and stakeholders in effective managerial decision making.

The study also identified Y Generation managers close affinity towards technology adoption in bringing stakeholder satisfaction. The success of any business depends upon effective satisfaction of supplier, customer, dealers, employee, employers, consultant etc. Adoption of technology provides speedy interaction between stakeholders and provides opportunities for the managers in strategic decision making. The last factor identifies by this case study is the visionary nature of Y Generation managers in the adoption of technology. A long term vision is required for any top leader in the organization to position their organization as a strategic entity in the midst of a volatile business environment. Thus, the attitude towards technology adoption of Y Generation managers is closely link to the strategic vision for sound organizational transformation.

\section{Conclusion and Implication}

Implication: This particular was undertaken to ascertain the factors that link to Y Generation manager's in their attitudes towards technology for business performance. The study provides a better understanding of my generation factors on their affinity towards technology adoption. This study a revelation to the human resource manager in their about the characteristic future of Y Generation and their basic attitude towards and their techno savvy attitude. It is necessary for the human resources manager for recruiting next generation managers in their organization. If modern human resources can orient their selection process towards the Y Generation may provide better workforce to the organization and its intern leads to business performance. Further research is also needed to recognize more inferential factors incorporating more experts from academic and corporate arena, by collecting data from various locations and with the application of quantitative research, which may provide better insight and understanding on Generation Y leader traits and characteristics.

Conclusion: This particular study on Y Generation manager's characteristic features is only utilized panel experts from one industrial location. Therefore, future research should include with more industrial leaders from different locations and incorporating industrialists, entrepreneurs, academicians, and researchers that identify, include and exclude factors related to leader traits and characteristic. Further application of quantitative analysis can produce more valid and reliable result.

\section{Reference}

Arsenault, P. M. (2004). Validating generational differences: A legitimate diversity and leadership issue. Leadership and Organizational Development Journal, 25(1/2).

Clark, A. D. (2007). The new reality: Using benefits to attract and retain talent. Employment Relations Today, 4, 47-53.

Crumpacker, M. \& Crumpacker, J. D. (2007). Succession planning and generational stereotypes: Should HR consider age-based values and attitudes a relevant factor or a passing fad? Public Personnel Management, 36(4), 349-69.

Custer, R. L., Scarcella, J. A. \& Stewart, B. R. (1999). The modified Delphi technique: A rotational modification. Journal of Vocational and Technical Education, 15(2), 1-10.

Dries, N., Pepermans, R. \& DeKerpel, E. (2008). Exploring four generations beliefs about career: Is satisfied the new successful? Journal of Management Psychology, 23(8), 907-928.

Dalkey, N. C. \& Helmer, O. (1963). An experimental application of the Delphi method to the use of experts. Management Science, 9(3), 458-467. 
Dalkey, N. C. (1972). The Delphi method: An experimental study of group opinion. In N. C. Dalkey, D. L. Rourke, R. Lewis, \& D. Snyder (Eds.). Studies in the quality of life: Delphi and decision-making (pp. 13-54). Lexington, MA: Lexington Books.

Delbecq, A. L., Van de Ven, A. H. \& Gustafson, D. H. (1975). Group techniques for program planning. Glenview, IL: Scott, Foresman, and Co.

Egri, C. P. \& Ralston, D. A. (2004). Generation cohorts and personal values: A comparison of China and the United States. Organization Science, 15(2), 210-220.

Clark, A. D. (2007). The new reality: Using benefits to attract and retain talent. Employment Relations Today, 2, 47-53

Essinger, C. (2006). Managing the millennial generation. Texas Library Journal, 82(3), 104-107.

Howe, N. \& Strauss, B. (2000). Millennials rising: The next greatest generation. New York: Vintage Books.

Kathryn Y. (2008).Responsibilities \& Leadership: Future of the profession: Recruiting and Managing the 'Why?' Generation: Gen Y. The CPA Journal, April.

King, Z. (2003). New or traditional careers? A study of UK graduates' preferences. Human Resource Management Journal, 13(1), 5-26.

Kupperschmidt, B. (2000). Multigeneration employees: Strategies for effective management. The Health Care Manager, 19, 65-76.

Loughlin, C. \& Barling, J. (2001).Young workers' values, attitudes, and behaviors. Journal of Occupational and Organizational Psychology, 74(4), 543-558.

Ludwig, B. G. (1994). Internationalizing Extension: An exploration of the characteristics evident in a state university Extension system that achieves internationalization. Unpublished doctoral dissertation. The Ohio State University, Columbus.

Ludwig, B. (1997). Predicting the future: Have you considered using the Delphi methodology? Journal of Extension, 35(5), 1-4. Retrieved November 6, 2005 URL: from http://www.joe.org/joe/1997october/tt2.html

Martin, C. A. (2005). From high maintenance to high productivity: What managers need to know about Generation Y. Industrial and Commercial Training, 37(1), 39-44.

Pfeiffer, J. (1968). New look at education. Poughkeepsie, NY: Odyssey Press. Rowh, M. (2007). Managing younger workers: Like it or not, even in the workplace, things go round and round in the circle game as a new generation moves to the forefront. Office Solutions, 34(1), 29.

Shaw, S. \& Fairhurst, D. (2008). Engaging a new generation of graduates. Education Training, 50(5), 366378.

Shih, W. \& Allen, M. (2007). Working with generation-D: Adopting and adapting to cultural learning and change. Library Management, 28(1/2), 89-100.

Smola, K. W. \& Sutton, C. D. (2002). Generational differences: Revisiting generational work values for the new millennium. Journal of Organizational Behavior, 23, 363-382.

Strauss, W. \& Howe, N. (1991). Generations: The history of America's future, 1584 to 2069. New York: Quill/William/Morrow.

Turoff, M. \& Hiltz, S. R. (1996). Computer based Delphi process. In M. Adler, \& E. Ziglio (Eds.).Gazing into the oracle: The Delphi method and its application to social policy and public health (pp. 56-88). London, UK: Jessica Kingsley Publishers.

Ulschak, F. L. (1983). Human resource development: The theory and practice of need assessment. Reston, VA: Reston Publishing Company, Inc.

Weingarten, R. M. (2009). Four generations, one workplace: A Gen X-Y staff nurse's view of team building in the emergency department. Journal of Emergency Nursing, 35, 27-30.

Westerman, J. W. \& Yamamura, J. H. (2007). Generational preferences for work environment fit: Effects on employee outcomes. Career Development International, 12(2), 150.

Zemke, R., Raines, C. \& Filipczak, B. (2000). Generations at work: Managing the clash of veterans, boomers, Xers and Nexters in your workplace (2nd ed.). New York: AMACOM.

\section{Interviews:}

Govind, G. R. HR Head, Continental Tyres (2012). Date of Interview (DOI): May 30th.

Hari, A. P. HR Manager, Maxis, (2012). Date of Interview (DOI): June 22nd.

Fiaza, A.S.A, Regional HR Manager, Metro Parking (2012). Date of Interview (DOI): August11 ${ }^{\text {th }}$. 